\title{
Kiris S.P.
}

\section{CONDOMINIUM - THE WESTERN EXPERIENCE AND UKRAINIAN PRACTICE}

\author{
Ukrainian State University of Chemical Technology, Dnipro, Ukraine
}

\begin{abstract}
The subject of this article is the Condominium - an Association of co-owners of apartment buildings in Ukraine. Condominium is the legal term used in the United States and in most provinces of Canada. Commonhold is a system of property ownership in England and Wales. In Australia, New Zealand and the Canadian province of British Columbia it is referred to as strata title. In Quebec the term «divided co-property» (French: co-propriйtй divisйe) is used, although the colloquial name remains «condominium». In France the equivalent is called copropriйtй (co-ownership), usually managed by the syndic. In Ukraine and most post-soviet countries this term used as Association of co-owners of apartment buildings or homeowners association - HOA (ob'ednannya spivvlasnikiv bagatokvartirnih budinkiv - OSBB). Condominiums role is to work with the owners' corporation and executive committee to successfully control, manage, maintain and administer the property and to create an appropriate community environment and includes tasks such as: general accounting, budgeting, invoicing of levies/service charges, arrears collections, financial reporting, contract management, meeting preparation, communication with property stakeholders, coordination of maintenance tasks, enforcement of rules/by-laws, issuance of notices, orders and certificates, general secretarial tasks. Purpose of the article is to analyze the existing forms of housing management in different countries and to describe the current status in Ukraine. The competitive environment of this market segment in Ukraine formed very slowly, and his condition is quite far from the market-oriented. It can not be formed to market-oriented conditions without an active policy of local councils.
\end{abstract}

Keywords: condominium, homeowners association, housing maintenance, communal services, maintenance tariffs.

DOI: $10.32434 / 2415-3974-2018-8-2-125-131$

\section{Introduction}

Housing maintenance and communal services in Ukraine - one of the most important industries.

It combines a range of services we need.

This is the sector of the economics which deals with the quality of life, satisfaction of human needs.

There are three basic methods of housing management exis in Ukraine:

1. Condominium, when the co-owners manage themselves by electing own Management and Chairman.

2. Management of an individual manager or a private management companies.

3. Administration by municipal management companies.

The subject of this work is Condominium - an Association of co-owners of apartment buildings ( «ob'ednannya spivvlasnikiv bagatokvartirnih budinkiv») in Ukraine, history and international practice of this problem, modern status of housing industry in Ukraine.

Formulation of the problem. A condominium is the form of housing tenure and other real property where a specified part of a piece of real estate (usually of an apartment house) is individually owned while use of and access to common facilities in the piece such as hallways, heating system, elevators, exterior areas is executed under legal rights associated with the individual ownership and controlled by the association of owners that jointly represent ownership of the whole piece.

\section{Analysis of publications}

The basis of the research is the works of such scholars and practitioners as O. S. Kovalenko, G. Polakoff, D. Landes, U. Kerr, and others.

However, it must be acknowledged that Ukraine lacks a sufficient theoretical base on this issue, and Western experience does not largely reflect modern 
economic conditions in Ukraine.

Condominium is the legal term used in the United States and in most provinces of Canada.

In Australia, New Zealand and the Canadian province of British Columbia it is referred to as strata title.

In Quebec the term «divided co-property» (French: co-proprin̆tй divisŭe) is used, although the colloquial name remains «condominium». In France the equivalent is called copropriйtй (соownership), usually managed by the syndic.

In Ukraine and most post-soviet countries this term used as Association of co-owners of apartment buildings or homeowners association - HOA (ob'ednannya spivvlasnikiv bagatokvartirnih budinkiv - OSBB).

Purpose of the article is to analyze the existing forms of housing management in different countries.

The main material. "Condominium" is a Latin word formed by adding the prefix con(«together») to the word dominium («domain, property, ownership»). Its meaning is therefore «shared property».

Condominia (the plural of condominium in Latin) originally referred to territories over which two or more sovereign powers shared joint dominion. This technique was frequently used to settle border disputes when multiple claimants could not agree on how to partition the disputed territory

The difference between an «apartment» complex and condominium is purely legal. There is no way to differentiate a condominium from an apartment simply by looking at or visiting the building. What defines a condominium is the form of ownership. A building developed as a condominium (and sold in individual units to different owners) could actually be built at another location as an apartment building (the developers would retain ownership and rent individual units to different tenants). As a practical matter, builders tend to build condominiums to higher quality standards than apartment complexes because of the differences between the rental and sale markets.

Technically, a condominium is a collection of individual home units and common areas along with the land upon which they sit. Individual home ownership within a condominium is construed as ownership of only the air space confining the boundaries of the home. The boundaries of that space are specified by a legal document known as a Declaration, filed on record with the local governing authority. Typically, these boundaries will include the wall surrounding a condo, allowing the homeowner to make some interior modifications without impacting the common area. Anything outside this boundary is held in an undivided ownership interest by a corporation established at the time of the condominium's creation. The corporation holds this property in trust on behalf of the homeowners as a group-it may not have ownership itself.

Condominiums have conditions, covenants, and restrictions, and often additional rules that govern how the individual unit owners are to share the space.

It is also possible for a condominium to consist of single-family dwellings. There are also «detached condominiums» where homeowners do not maintain the exteriors of the dwellings, yards, etc. and «site condominiums» where the owner has more control and possibly ownership (as in a «whole lot» or «lot line» condominium) over the exterior appearance. These structures are preferred by some planned neighborhoods and gated communities.

The first condominium law passed in the United States was in the Commonwealth of Puerto Rico in 1958. In 1960, the first condominium in the Continental United States was built in Salt Lake City, Utah[1]. The legal concept had spread to the United States from Europe via the Caribbean (Puerto Rico and Cuba) but throughout the 1960s it was widely and erroneously reported that the concept had arisen in the United States directly based on an Ancient Roman model. In fact the concept of an estate in the air was antithetical to Roman Law and there is no evidence of an ancient Roman «condominio»[2].

Section 234 of the Housing Act of 1961 allowed the Federal Housing Administration to insure mortgages on condominiums, leading to a vast increase in the funds available for condominiums, and to condominium laws in every state by 1969.[3]. Many Americans' first widespread awareness of condominium life came not from its largest cities but from South Florida, where developers had imported the condominium concept from Puerto Rico and used it to sell thousands of inexpensive homes to retirees arriving flush with cash from the urban Northern United States.

The primary attraction to this type of ownership is the ability to obtain affordable housing in a highly desirable area that typically is beyond economic reach. Additionally, such properties benefit from having restrictions that maintain and enhance value, providing control over blight that plagues some neighborhoods.

Over the past several decades, the residential condominium industry has been booming in all of the major metropolitan areas such as Miami, SanFrancisco, Seattle, Boston, Chicago, Austin, Los Angeles and New York City. However, in recent years, supply within the condo industry has caught up with demand and sales have slowed. It is now in a slowdown phase.

An alternative form of ownership, popular in parts of the United States but found also in other common law jurisdictions, is housing cooperative, also known as «company share» or 
«condominiim». A Housing Cooperative is where the building has an associated legal company and ownership of shares gives the right to a lease for residence of a unit [4]. Another form is ground rent (solarium) in which a single landlord retains ownership of the land (solum) but leases the surface rights (superficies) which renew in perpetuity or over a very long term. This is comparable to a civillaw emphyteusis, except that emphyteusis shifts the duties of up-keep and making improvements onto the renter.

In the United States, there are several different styles of condominium complexes. For example, a garden condominium complex consists of low-rise buildings built with landscaped grounds surrounding them. A townhouse condominium complex consists of multi-floor semi-detached homes. In condominium townhouses, the purchaser owns only the interior, while the building itself is owned by a condominium corporation. The corporation is jointly owned by all the owners, and charges them fees for general maintenance and major repairs. Freehold townhouses are exclusively owned, without any condominium aspects. In the United States this type of ownership is called fee simple.

Commonhold is a system of property ownership in England and Wales. It involves the indefinite freehold tenure of part of a multioccupancy building (typically a flat) with shared ownership of and responsibility for common areas and services. It has features of the strata title and the condominium systems, which exist in Australia and the United Statesres pectively. It was introduced by the Commonhold and Leasehold Reform Act 2002 as an alternative to leasehold, and was the first new type of legal estate to be introduced in English law since 1925.

An important difference between commonholds on the one hand and leaseholds (leases) on the other is that commonholds do not depreciate in value towards the end of their Term (term, term of years or in extraneous documents sometimes existence).

In the years since the 2002 Act became law, only a handful of commonholds have been registered, whilst hundreds of thousands of long leases have been granted during the same period. As of 3 June 2009 , there were 12 commonhold residential developments comprising 97 units (homes) in England and one commonhold residential development comprising 30 units (homes) in Wales.

Where freehold houses should be subjected to positive covenants which force their owners contribute to communal maintenance, such as in garden squares, as few such duties can attach to freeholds, access to such areas can be physically restricted to those who own that area, commonly through a residents' Management Company. Such a company if the land was owned by the original landlord such as a developer may come into the hands of the lessees (tenants) through a statutory process of the Right to Manage leading to legal agreements or a court order which creates a limited liability Right to Manage (also known as an RTM) Company. A common alternative has been rentcharges where truly necessary services or contributions need to be made which cannot devolve to a local authority or statutory undertaker through adoption.[5].

Strata title was first introduced in 1961 in the state of New South Wales, Australia, to better cope with the legal ownership of apartment blocks. Previously, the only adequate method of dividing ownership was company title, which had a number of defects, such as the difficulty of instituting mortgages. This term also applies to house-type strata title units in Australia.

Strata Title Schemes are composed of individual lots and common property. Lots are either apartments, garages or storerooms and each is shown on the title as being owned by a Lot Owner. Common Property is defined as everything else on the parcel of land that is not comprised in a Lot, such as common stairwells, driveways, roofs, gardens and so on.

In New Zealand, Strata Title, commonly called a Unit Title, is created by the Unit Titles Act 2010.

A Unit Title can be either a Stratum in Freehold, where the owners own the underlying land, or Stratum in Leasehold, where another person owns the land and the body corporate pays rent to that person. As New Zealand uses the Torrens System of indefeasible titles, the title for a Unit Title has a title for the Principal Unit, showing the legal description of the Principal Unit and any Accessory Units and any legal document registered against those units (called an interest); a Supplementary Record Sheet, showing the rules of the body corporate, its registered address and any interests registered against the underlying land; and the survey plan, which shows the boundaries of the units and the common property.

A person purchasing a Unit Title purchases a Principal Unit, which is designed as a place of business or residence; any accessory units included in the title for the principal unit, such as car parks and storage lockers; and a beneficial interest in the common property, such as corridors, air ducts, building structure and entry ways; and membership in the body corporate, which is composed of all unit owners and which legally owns the common property.

Creation of a unit title is a type of subdivision and so requires the approval of the relevant territorial authority under the Resource Management Act 1991, as well as under the Unit Titles Act 2010. A unit plan must be deposited with Land Information New Zealand and new titles issue in respect of each principal unit. 
The body corporate is responsible for maintaining the common property and the structure of the building (if this duty is delegated by the owners), and for insuring the common property and the building structure. The body corporate can set rules governing the use of the common property (for example, an owner who causes damage must repair it) and the units (for example, no keeping pets or making noise after a certain time), and for the regulation of the body corporate. These rules must be registered and non-registered rules do not have legal effect. The operations of the body corporate are paid for by levies on all owners. Levies are assigned based on the ownership interest or utility interest of the particular unit. An ownership interest is based on the value of the unit, while a utility interest is either the ownership interest or a proportion that is fair and equitable having regard to the costs and benefits of the unit.

The owners in the unit title development must meet yearly to approve the levies, the financial statements, long term maintenance plan and fund (if any), approve changes to the body corporate rules (if any), and the appointment of the body corporate chairman and committee (if any). The body corporate can delegate most of their duties to the committee of the owners. The body corporate can also enter into service agreements in respect of the administration of the body corporate, usually to a specialist body corporate management firm, and building maintenance, including appointing a building manager. These service agreements must be permitted under the body corporate rules.

A body corporate must have a Long Term Maintenance Plan, which provides for maintenance of the common property for at least ten years and an estimate of the costs. The Long Term Maintenance Plan is then paid for by the Long Term Maintenance Fund, which must be separate from the body corporate general operating fund. However, a body corporate can elect not to have a Long Term Maintenance Fund. Disputes under the Unit Titles Act are heard in the Tenancy Tribunal.[6].

Strata management, sometimes known as «body corporate management», is a specialist area of property management involving the day-to-day operation and management of a property that is jointly owned and comprises multiple units, common areas and common facilities. It is derived from an Australian concept of property law called strata title applied to the administration of common ownership in apartment buildings on multiple levels, or strata. It is one of the fastest growing forms of housing in the United States today, similar to common-interest evelopment (CID), a category that includes planned unit developments of singlefamily homes, known as homeowner associations (HOAs), condominiums, and cooperative apartments.

The successful management of such developments requires the establishment of a strata title system to provide a framework for ownership, and guidelines to manage developments with multiple users and owners.

Many jurisdictions adopt the concept of jointlyowned property. Owners in these types of schemes automatically become members of an owners' or community association. These associations ultimately bear responsibility for the maintenance and management of common areas such as lobbies and corridors, and shared leisure facilities such as swimming pools and gyms. They are also responsible for running the administrative and financial aspects of the property.

The strata manager's role is to work with the owners' corporation and executive committee to successfully control, manage, maintain and administer the property and to create an appropriate community environment and includes tasks such as:

- General accounting;

- Budgeting;

- Invoicing of levies/service charges;

- Arrears collections;

- Financial reporting;

- Contract management;

- Meeting preparation;

- Communication with property stakeholders;

- Coordination of maintenance tasks;

- Enforcement of rules/by-laws;

- Issuance of notices, orders and certificates;

- General secretarial tasks [7].

A OSBB board of directors is elected by the membership, providing a voice and representation in the governance of the property. Rules are determined by the board, providing a flexible means of addressing the issues that arise in a community to assure the members' peaceful possession of their homes.

A housing cooperative is normally de facto nonprofit, since usually most of its income comes from the rents paid by its residents (if in a formal corporation, then shareholders), who are invariably its members. There is no point in creating a deliberate surplus-except for operational requirements such as setting aside funds for replacement of assets-since that simply means that the rents paid by members are set higher than the expenses. (Note, however, that it's quite possible for a housing condominiim to own other revenue-generating assets, such as a subsidiary business which could produce surplus income to offset the cost of the housing, but in those cases the housing rents are usually reduced to compensate for the additional revenue.)

New condominiims are often founded by the builder, who resigns from the condominiim when all the shares have been sold. It is relatively difficult 
to start a housing condominiim from scratch because if the idea is, for instance, to build a building or group of buildings to house the members, this usually takes a significant mortgage loan for which a financial institution will want assurances of responsibility. It may also take a year or more for the members to organize the design and construction, as well as time and foresight to establish even basic organizational policies. It is rare that these kinds of skills of organization are available in a random group of people who often have pressures on their existing housing. It may be somewhat easier to organize a group of closely related housing units. This opportunity may arise, for example, if an existing apartment building's owner is thinking about selling it.

In the lifecycle of buildings, the replacement of assets (capital repairs) requires significant funds which can be obtained through a variety of ways: assessments on current owners; sales of Treasury Stock (former rental units) to new shareholders; draw downs of reserves; unsecured loans; operating surpluses; fees on the sales of units between shareholders and new and increases to existing mortgages.

\section{Conclusions}

Condominiums are simultaneously consolidated consumer (the representative of all co-owner) and consolidated performer (the representative of all contractors that provide maintenance and service). This greatly simplifies the end-user relationships with other market players.

In Ukraine, members of a OSBB typically elect a board of directors from amongst the shareholders at a general meeting, usually the annual general meeting.

Condominiums role is to work with the owners' corporation and executive committee to successfully control, manage, maintain and administer the property and to create an appropriate community environment and includes tasks such as:

- General accounting;

- Budgeting

- Invoicing of levies/service charges

- Arrears collections

- Financial reporting

- Contract management

- Meeting preparation

- Communication with property stakeholders

- Coordination of maintenance tasks

- Enforcement of rules/by-laws

- Issuance of notices, orders and certificates

- General secretarial tasks

During 2015-2018 a number of registered condominiums (OSBB) in Ukraine greatly increased and reached over 30 thousand.

Housing maintenance and communal services in Ukraine - one of the most important industries.
It combines a range of services we need. This is the sector of the economics which deals with the quality of life, satisfaction of human needs. And the condominiums is the main subject of this industry.

Market housing and utilities - a set of relations that arise between suppliers of utility services and their customers.

Most of the market housing and public utilities owned by natural monopoly. There are heating, water, electricity, and gas supply. The competitive environment occurs only in specific market segments: solid waste removal, cleaning of areas, maintenance of elevators and networks.

Market development of housing services is constrained by the fact that the activities of businesses is economically unattractive because of overregulation of the market, difficulty or inability to enter the market.

Small private management company that could be the drivers of competition artificially disallowed at the market. Unlike major competitors are flexible and interested in every client, which are not so much they could be the provision of comprehensive maintenance of houses and condominiums become reliable partners.

Unlike municipal management companies that are funded from local budgets and do not include the cost, condominiums guided only their estimate, which over 99 percent consists of owners contributions.

Co-owners would like to get more ranges of services and better quality, but on the other hand do not want to pay more.

In addition, municipal management companies artificial obstacles newly condominiums - hide the technical documentation under various pretexts, denies access to networks and so on.

The competitive environment in this market segment formed very slowly, and his condition is quite far from the market-oriented. It can not be formed to market-oriented conditions without an active policy of local councils.

\section{REFERENCES}

1. Natelson, Robert (1987). »Comments on the Historiography of Condominium: The Myth of Roman Origin» [Electronic resource]. - Access mode: https://i2i.org/wp-content/ uploads/2010/09/Comments-on-the-Historiography-ofCondominium-The-Myth-of-Roman-Origin.pdf

2. Poliakoff, G: Law of Condominium Operations, $§ 1.2$. 2009. [Electronic resource]. - Access mode: http://legalsolutions. thomsonreuters.com/law-products/Practitioner-Treatises/TheLaw-of-Condominium- Operations /p/100027800

3. Kerr, William (2013). »Condominium - Statutory Implementation». St.John's Law Review 38 [Electronic resource]. - Access mode: http://scholarship. law.stjohns.edu/cgi/ 
viewcontent.cgi? article $=4266 \&$ context $=$ lawreview.

4. Clarke, Katherine (13 June 2014). »Sales slow at highend condos as pricey pads grow plentiful around city»[Electronic resource]. - Access mode: http://www.nydailynews.com/life-style/ real-estate/occupy-w-57th-st-article-1.1827613

5. House of Commons of the United Kingdom, Michael Wills Written Questions, 9 June 2009 col. 792W Commonhold [Electronic resource]. - Access mode: https:// www.theyworkforyou.com/wrans/?id=2009-06-09c.278364.h

6. Unit Titles Act 2010[Electronic resource]. - Access mode: http://www.legislation.govt.nz/act/public/2010/0022/latest/ DLM1160440.html

7. Strata Living, FT045, May 2015, NSW Government Fair Trading [Electronic resource]. - Access mode: http:// www.waverley.nsw.gov.au/_data/assets/pdf_file/0008/162773/ Strata_Living.pdf

Received 17.10.2018

Reviewer: Doct of Econ. Sc., prof. Pozhueva T.O.

\section{КОНДОМІНІУМ - ЗАХІДНИЙ ДОСВІД І УКРАЇНСЬКА ПРАКТИКА}

Kipic C.I.

Предметом иієї статті є Кондомініум - Асоціація співвласників багатоквартирних будинків України. Кондомініум - юридичний термін, який використовується в Сполучених Штатах та у більшості провінцій Канади. В Англії та Уельсі - це Coтmonhold. У Австралії, Нової Зеландії та канадській провінції Британська Колумбія це називають стратами. У Квебеку використовується термін «розділене співвласність» (франиузька: co-propriŭtŭ divisŭe), хоча розмовна назва залишається «кондомініум». У Франції еквівалент називається сорторгійтй (спільна власність), який зазвичай управляється синдиком. В Україні та більщості пострадянських країн цей термін використовується як Об’єднання співвласників багатоквартирних будинків або ассоціація власників житла ОСББ). Роль кондомініуму - це робота з суспільною власністю та роль виконавчого комітету для успішного управління, обслуговування та адміністрування майна та створення відповідного середовища для громади. Включає в себе такі завдання, як: загальний облік, бюджетування, виставлення рахунків зборів/плати за послуги, збор заборгованості із внесків, фінансова звітність, управління договорами, підготовка зборів співвласників, спілкування з контрагентами, координація завдань з обслуговування, виконання норма, правил обслуговування мереж, видача довідок, повідомлень та іншої інформації, загальні завдання. Метою статті є аналіз існуючих форм управління житлом в різних країнах та опис поточного стану в Україні. Конкурентне середовище иього ринку в Украӥні формується дуже повільно, і його стан досить далекий від ринкового. Він не може бути сформований на ринкових умовах без активної політики місцевих рад.

Ключові слова: кондомініум, об'єднання домовласників, житлове обслуговування, комунальні послуги, тарифи на обслуговування.

\section{КОНДОМИНИУМ - ЗАПАДНЫЙ ОПЫТ И УКРАИНСКАЯ ПРАКТИКА}

Кирис С.II.

Предметом этой статьи является кондоминиум - Обіединение совладельцев многоквартирных домов. Кондоминиум - юридический термин, используемый в Соединенных ШІататах и в большинстве провинций Канады. В Англии и Уэльсе - это Commonhold. В Австралии, Новой Зеландии и канадской провинции Британская Колумбия это называют strata (cmpaта). В Квебеке используется термин «раздельное совладение» (франиузский: со-propriŭtŭ divisŭe), хотя разговорное название остается «кондоминиум». Во Франции эквивалент называется сортортійтй (совместная собственность), который обычно управляется синдиком. В Украине и большинстве постсоветских стран этот термин используется как Объединение совладельцев многоквартирных домов или ассоциация собственников жилья - ОСМД). Роль кондоминиума - это работа с совместной собственностью и роль исполнительного комитета для успешного управления, обслуживания и администрирования имущества и создания соответствующей среды для общества. Включает в себя такие задачи, как: общий учет, бюджетирование, выставление счетов / платы за услуги, собрание задолженности по взносам, финансовая отчетность, управление договорами, подготовка собраний совладельцев, общение с контрагентами, координация задач по обслуживанию, выполнение норм, правил обслуживания сетей, выдача справок, сообщений и другой информации, общие задачи. Целью статьи является анализ существующих форм управления жильем в разных странах и описание текущего состояния в Украине.

Ключевые слова: кондоминиум, объединения домовладельцев, жилищное обслуживание, коммунальные услуги, тарифы на обслуживание. 